JURNAL PENDIDIKAN, p-ISSN 2715-095X, e-ISSN 2686-5041

Volume 30, No.1, Maret 2021 (53-58)

Online: http://journal.univetbantara.ac.id/index.php/jp

\title{
Dampak Pembelajaran Jarak Jauh Pada Masa Covid-19 di SMK Muhammadiyah 1 Sukoharjo
}

\author{
Salma Rahma Chrisya Adriani, Sinung Khoirot, Sawitri ${ }^{{ }^{*}}{ }^{*}$, dan Nurjanah
}

Program Studi Pendidikan Bahasa dan Sastra Daerah, Fakultas Keguruan dan Ilmu Pendidikan, Universitas Veteran Bangun Nusantara Sukoharjo

Alamat: J1. Letjend. Sujono Humardani 1 telp. (0271)593156 Sukoharjo-Jawa Tengah

e-mail: salmarahmaca@gmail.com/089654488279

\author{
CA*Corresponding Author
}

\begin{abstract}
Abstrak: Penyebaran Covid-19 di Indonesia yang semakin meluas dan memakan banyak korban.Salah satu upaya pemerintah untuk mengurangi penyebaran virus ini adalah membuat kebijakan bagi para pelajar di seluruh Indonesia untuk belajar di rumah tetapi pembelajaran tetap terus berjalan yakni dengan cara pengajar dan peserta didik menggunakan media daring atau online, pembelajaran tatap muka harus diubah menjadi pembelajaran online dan proses pembelajaran dilakukan dengan menggunakan Microsoft Office 365. Penelitian ini bertujuan mengetahui dampak apa yang terjadi dalam Pembelajaran Jarak Jauh pada masa Pandemi Covid-19 di SMK Muhammadiyah 1 Sukoharjo. Selain itu penelitian ini bermanfaat untuk mengetahui tanggapan dari para siswa SMK Muhammadiyah 1 Sukoahrjo dalam hal proses pengajaran yang diterapkan semenjak pandemic ini. Penelitian ini menggunakan metode penelitian kualitatif eksploratif dengan pendekatan perspektif. Hasil dari penelitian ini dapat diketahui banyak sekali dampak yang diperoleh baik teknis maupun guru mengetahui bahwa siswa kurang puas, siswa kurang puas dengan metode PJJ yang mereka gunakan saat ini, dan guru juga kurang puas dengan kemampuan guru menyampaikan materi kesiswa.
\end{abstract}

Kata-kata Kunci: dampak pembelajaran jarak jauh, pembelajaran daring, covid-19.

\section{Impact of Distance Learning during the Covid-19 Period at SMK Muhammadiyah 1 Sukoharjo}

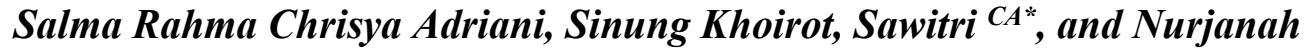

Program StudiPendidikan Bahasa dan Sastra Daerah, Fakultas Keguruan dan Ilmu Pendidikan, Universitas Veteran Bangun Nusantara Sukoharjo

Alamat: Jl. Letjend. Sujono Humardani 1 telp. (0271)593156 Sukoharjo - Jawa Tengah

E-mail: salmarahmaca@gmail.com/089654488279

CA*Corresponding Author

\begin{abstract}
The spread of Covid-19 in Indonesia is increasingly widespread and has claimed many victims. One of the government's efforts to reduce the spread of this virus is to make policies for students all over Indonesia to study at home but learning continues, namely by teaching and learning media online or online, face-to-face learning must be converted into online learning and the learning process is carried out using Microsoft Office 365. This study aims to determine the impact of what happened in Distance Learning during the Covid-19 Pandemic at SMK Muhammadiyah 1 Sukoharjo. In addition, this study is useful for knowing the responses of the students of SMK Muhammadiyah 1 Sukoahrjo in terms of the teaching process that has been implemented since this pandemic. This study uses a qualitative exploratory research method with a perspective approach. The results of this study can be seen that there
\end{abstract}


are many impacts obtained both technically and by the teacher knowing that students are less satisfied, students are not satisfied with the PJJ method they are currently using, and teachers are also less satisfied with the teacher's ability to deliver material to students.

Keywords : Impact of distance learning, online learning, covid-19.

\section{Pendahuluan}

Covid-19 merupakan virus baru yang mewabah pertama kali di Wuhan, Tiongkok pada bulan Desember 2019.Virus ini menular dan penyebarannya sangat cepat hingga ke seluruh penjuru dunia, serta memakan banyak korban jiwa, tidak terkecuali di Indonesia. Akibat pandemi Covid-19 tersebut, berbagai kebijakan telah diterapkan untuk memutus mata rantai penularan virus Covid-19 di Indonesia. Salah satu upaya yang dilakukan oleh pemerintah Indonesia adalah mengajak masyarakat untuk menjaga jarak secara fisik (Physical Distancing) yaitu menjaga jarak antar masyarakat, menjauhi segala bentuk keramaian, pergaulan, dan untuk menghindari pertemuan banyak orang (Suyahman, 2020). Upaya ini ditujukan untuk masyarakat, sehingga dapat memutus rantai penyebaran Covid19 yang saat ini sedang terjadi. Pemerintah menerapkan kebijakan yang disebut Work from Home (WFH). Kebijakan ini merupakan upaya agar masyarakat dapat melakukan segala pekerjaannya di rumah. Pendidikan di Indonesia juga menjadi salah satu yang terdampak pandemi Covid-19. Karena adanya pembatasan interaksi, Kementerian Pendidikan RI juga mengeluarkan kebijakan untuk membubarkan sekolah dan mengganti proses kegiatan belajar mengajar (KBM) dengan sistem online. Dengan menggunakan sistem pembelajaran online ini, terkadang terdapat berbagai masalah yang dihadapi siswa dan guru, seperti topik yang belum diselesaikan oleh guru, kemudian guru menggantinya dengan tugas lain. Ini merupakan keluhan bagi siswa karena guru memberikan lebih banyak pekerjaan rumah. Office 365 adalah situs jaringan pendidikan yang menyediakan platform online yang aman untuk guru dan siswa. Aplikasi Microsoft terbaru ini dirancang untuk mempermudah komunikasi dan memudahkan pengguna untuk mengaksesnya di perangkat lain. Misalnya komputer dan smartphone yang digunakan untuk mengirim email, dokumen, konferensi video, Microsoft Office 365 memiliki fungsi komunikasi yang disebut Exchange Online, dan memiliki fungsi lengkap yang dapat digunakan dalam pendidikan untuk belajar dengan mudah dan dapat diakses secara online. Siswa menanggapi semua materi dan soal online yang diberikan oleh guru melalui perangkat Office 365 tersebut. Tujuan dari penelitian ini untuk mengetahui dampak apa saja yang dialami para siswa dalam pembelajaran jarak jauh pada masa covid-19 ini.

\section{Metode Penelitian}

Penelitian ini merupakan penelitian kualitatif dengan menggunakan metode deskriptif kualitatif. Menurut Sugiyono (2009: 15) penelitian kualitatif adalah suatu metode penelitian yang berlandaskan filsafat postpositivisme, digunakan untuk meneliti pada kondisi objek yang alamiah dimana peneliti adalah sebagai instrument kunci, pengambilan sampel data bersifat kualitatif, dan hasil penelitian kualitatif lebih menekan kan makna dari pada generalisasi. Objek informasi dalam penelitian ini adalah siswa SMK Muhammadiyah 
1 Sukoharjo yang telah mendapatkan pelatihan PJJ. Metode pengumpulan data dilakukan dengan menyebarkan angket/kuesioner. Kuesioner dilakukan sampai data utama dikumpulkan dalam waktu sekitar 3 hari. Kuesioner dilakukan dalam bentukpertanyaan. Metode ini digunakan untuk memperoleh informasi tentang dampak dari pembelajaran jarak jauh pada kejadian pandemi Covid-19 SMK Muhammadiyyah 1 Sukoharjo. Dalam penelitian kualitatif ini tidak menggunakan istilah populasi, melainkan dalam Sugiyono (2007: 49) dinamakan social situation atau situasi social yang terdiri atas tiga elemen yaitu tempat pelaku dan aktivitas yang berinteraksi secara sinergis. Dalam penelitian ini terdapat 4 responden yang relevan dari SMK Muhammadiyah Sukoharjo yaitu 1 guru dan 3 siswa.

Tabel 1. Responden

\begin{tabular}{ccc}
\hline Inisial & Jenis kelamin & Jabatan \\
\hline Responden 1 & Laki-laki & Siswa \\
Responden 2 & Laki-laki & Siswa \\
Responden 3 & Laki-laki & Siswa \\
Responden 4 & Perempuan & Guru \\
\hline
\end{tabular}

Wawancara terstruktur dilakukan terhadap pertanyaan-pertanyaan yang telah disusun, dihubungkan dan dikembangkan dengan literatur yang relevan. Sampel yang diambil menggunakan metode purposive sample. Menurut fuad zainul, dkk (2019: 82) metode ini merupakan metode pengambilan sampel yang banyak digunakan pada penelitian yang kondisi status suatu wilayah, kondisi geografis, keanekaragaman hayati pada suatu wilayah apabila kondisinya cenderung heterogen. Kondisi tersebut menyebabkan peneliti mengalami kesulitan untuk mendapatkan sampel jika tidak ada unsur kesengajaan dalam pengambilan sampel tersebut. Sugiono (2011: 84) mengatakan bahwa purposive sample adalah teknik untuk menentukan sampel dengan pertimbangan khusus. Penelitian eksploratif adalah salah satu jenis penelitian sosial yang tujuannya untuk memberikan sedikit definisi atau penjelasan mengenai konsep atau pola yang digunakan dalam penelitian (Hermawan, 2008: 17). Peneliti bersiap untuk mengajukan pertanyaan dalam wawancara dengan responden. Semua informasi yang diperoleh peneliti dari wawancara disertai dengan persetujuan peneliti dan persetujuan orang yang diwawancarai.Untuk mendapatkan hasil survei melalui analisis, peneliti memilah beberapa pertanyaan sebagai bahan untuk berdiskusi dan memperoleh informasi dari responden. Berikut beberapa pertanyaan yang telah diajukan oleh peneliti: (a). Bagaiman proses belajar siswa dimasa pandemi ? (b). Kendala apa yang dihadapi siswa dalam proses PJJ (pembelajaran jarak jauh)? (c). Apakah siswa mudah mempelajari materi yang diberikan oleh guru ? (d). Apakah metode PJJ tepat diterapakan dalam proses pembelajaran ? (e). Apakah siswa merasa puas dengan kemampuan guru saat menyampaikan materi dalam pembelajaran jarak jauh?

\section{Hasil Penelitian}


Peneliti disini menggunakan teknik wawancara kepada 4 responden dan didapatkan hasil untuk menjawab pertanyaan mengenai dampak pembelajaran jarak jauh pada masa covid-19 di SMK Muhammadiyah 1 Sukoharjo. Berikut hasil wawancara dari ke-4 responden.

Responden 1: (1). Bagaimana proses belajar siswa dimasa pandemi ? Jawabanresponden: belajarsecara daring. (2). Kendala apa yang dihadapi siswa dalam proses PJJ (pembelajaran jarak jauh)? Jawaban responden: sinyal hp yang terkadang musermuser (3). Apakah siswa mudah mempelajari materi yang diberikan oleh guru ? (4). Jawaban responden: kurang memahami karena penyampaiannya kurang jelas. (5). Apakah metode PJJ tepat diterapakan dalam proses pembelajaran? Jawaban responden: karena ada corona menurut saya tepat. Apakah siswa merasa puas dengan kemampuan guru saat menyampaikan materi dalam pembelajaran jarak jauh? Jawaban responden: puas karena biasanya diakhir pembelajaran disertakan video penjelasan materi dari youtube

Responden 2: (1). Bagaimana proses belajar siswa dimasa pandemi ? Jawaban responden: kurang efektif. (2). Kendala apa yang dihadapi siswa dalam proses PJJ? Jawaban responden: kurang memahami materi yang disampaikan dan kuota cepet habis. (3). Apakah siswa mudah mempelajari materi yang diberikan oleh guru? Jawaban responden: kadang bisa memahami kadang tidak. (4). Apakah metode PJJ tepat diterapakan dalam proses pembelajaran? Jawaban responden: kurang tepat. (5). Apakah siswa merasa puas dengan kemampuan guru saat menyampaikan materi dalam pembelajaran jarak jauh? Jawaban responden: kurang puas.

Responden 3: (1). Bagaimana proses belajar siswa dimasa pandemi? Jawaban responden: proses belajar ini saya menemui banyak kesulitan dalam proses belajar. (2). Kendala apa yang dihadapi siswa dalam proses PJJ? Jawaban responden: kuota dan sinyal yang terkadang tidak bersahabat. (3). Apakah siswa mudah mempelajari materi yang diberikan oleh guru? Jawaban responden: kurang memahami karena guru hanya member materi inti pokok dari mata pelajaran tersebut, tidak dijelaskan sampai detail. (4). Apakah metode PJJ tepat diterapakan dalam proses pembelajaran? Jawaban responden: kurang tepat karena tidak bisa bertatap muka langsung dengan guru untuk menyaimpaikan materi. (5). Apakah siswa merasa puas dengan kemampuan guru saat menyampaikan materi dalam pembelajaran jarak jauh? Jawaban responden: sangat kurang puas.

Responden 4: (1). Bagaimana proses belajar siswa dimasa pandemi? Jawaban responden: selama masa pandemi proses belajar siswa secara online atau daring menggunakan aplikasi Office 365. (2). Kendala apa yang dihadapi siswa dalam proses PJJ? Jawaban responden: kemungkinan sinyalnya yang tidak bisa untuk membuka materi yang sudah disiapkan oleh guru di aplikasi Office 365. (3). Apakah siswa mudah mempelajari materi yang diberikan oleh guru? Jawaban responden: insyaallah mudah, karena sebisa mungkin saya menyampaikan materi yang simple, mudah dipelajari, dan menarik minat siswa. (4). Apakah metode PJJ tepat diterapakan dalam proses pembelajaran? Jawaban responden: sebenarnya kurang tepat karena bisa menghambat siswa dalam menangkap 
materi, tapi karena sudah menjadi kebijakan dari pemerintah dan demi memutus mata rantai covid-19 kita harus melaksanakannya dan mematuhinya. (5). Apakah siswa merasa puas dengan kemampuan guru saat menyampaikan materi dalam pembelajaran jarak jauh? Jawaban responden: terkadang ada yang merasa puas ada yang tidak. Mungkin karena siswa sudah merasa bosan belajar daring.

\section{Pembahasan}

Dari hasil wawancara tersebut peneliti dapat menyimpulkan bahwa banyak sekali dampak dari pembelajaran jarak jauh dimasa pandemic covid-19 ini, dilihat dari siswa melaksakan belajar mandiri dengan cara mempelajari materi, diskusi secara online, dan dampak yang diterima siswa. Terkait dengan tujuan penelitian ini berdasarkan hasil wawancara dengan 4 responden tentang dampak pembelajaran jarak jauh pada masa covid19 di SMK Muhammadiyah 1 Sukoharjo adalah (1) terkait proses belajar siswa dimasa $p$ andemic yang menurut siswa dan guru kurang efektif, (2) banyak kendala yang dihadapi selama belajar daring mulai dari kuota habis dan sinyal yang kurang mendukung proses belajar, (3) kurang pahamnya siswa dengan materi yang telah disampaikan oleh guru karena kurangnya minat siswa dalam belajar, (4) kebijakan pemerintah untuk dirumah aja membuat kurang tepatnya metode pembelajaran jarak jauh ini, (5) tidak diperbolehkannya untuk bertatap muka membuat guru kesulitan untuk menyampaikan materi kepada siswa. Di balik masalah dan keluhan tersebut, ternyata juga terdapat berbagai hikmah bagi pendidikan di Indonesia. Diantaranya, siswa maupun guru dapat menguasai teknologi untuk menunjang pembelajaran secara online ini. Di era disrupsi teknologi yang semakin canggih ini, guru maupun siswa dituntut agar memiliki kemampuan dalam bidang teknologi pembelajaran. Penguasaan siswa maupun guru terhadap teknologi pembelajaran yang sangat bervariasi, menjadi tantangan tersendiri bagi mereka. Dengan adanya kebijakan WFH, maka mampu memaksa dan mempercepat mereka untuk menguasai teknologi pembelajaran secara digital sebagai suatu kebutuhan bagi mereka. Tuntutan kebutuhan tersebut, membuat mereka dapat mengetahui media online yang dapat menunjang sebagai pengganti pembelajaran di kelas secara langsung, tanpa mengurangi kualitas materi pembelajaran dan target pencapaian dalam pembelajaran. Berbagai media pembelajaran jarak jauh pun dicoba dan digunakan.

\section{Simpulan dan Saran}

Pandemi Covid-19 saat ini telah memengaruhi banyak aspek, termasuk sektor pendidikan. Khusus di SMK Muhammadiyah 1 Sukoharjo, sebagai contoh sebuah lembaga pendidikan vokasi sekolah menengah atas, akibat pandemi Covid-19 harus mengikuti cara pembelajaran. Berdasarkan hasil penelitian, guru mengetahui bahwa siswa kurang puasdengansistembelajar online, siswa kurang puas dengan metode PJJ yang mereka gunakan saat ini. Seperti yang kita ketahui bersama, pengaruh sistem pendidikan jarak jauh pasti akan berdampak baik dan buruk bila diperbarui. Dalam pembelajaran jarak jauh 
dampak buruk bagi siswa terbatasnya kuota, karena siswa harus memiliki kuota Internet dan hak akses Internet yang memadai untuk melakukan pendidikan jarak jauh berbasis online, sinyal yang kurang mendukung proses belajar, dan kesulitan siswa dalam memahami materi sedangkan dampak buruknya siswa maupun guru tidak terinveksi virus berbahaya ini yaitu virus covid-19. Mungkin saran bagi guru untuk membuat materi semenarik mungkin agar menarik minat belajar siswa dan penjelasan materi yang tidak terlalu monoton agar siswa mudah memahami materi yang disampaikan, juga pentingnya peran orang tua untuk selalu mengawasi anaknya ketika sedang sekolah online maupun belajar.

\section{Daftar Rujukan}

Achmad. Jayul,.\& Edi. Irwanto. (2020). Model Pembelajaran Daring Sebagai Alternatif Proses Kegiatan Belajar Pendidikan Jasmani di Tengah Pandemi Covid-19. Jurnal Pendidikan Kesehatan Rekreasi, volume 6(2), hal: 199, Juni 2020, DOI: 10.5281/zendo.3892262.

Arikunto. (2006). Prosedur Penelitian Suatu Pendekatan Praktek. Jakarta: PT. Rineka Cipta.

Fuad, Zainul, dkk. (2019). Metode Penelitian Kualitatif. Bandung: Remaja Rosdakarya. (2009). Metode Penelitian Kuantitatif, Kualitatif dan R\&D. Bandung: Alfbeta.

Matdio. Siahaan. (2020). Dampak Pandemi Covid-19 Terhadap Dunia Pendidikan. jurnal

Karya Ilmiah. Edisi Khusus No. 1 (Juli 2020), hal: 1-3. Fakultas Ekonomi

Universitas Bhayangkara Jakarta Raya.

Nureza. Fauziyah. (2020). Dampak Covid-19 Terhadap Efektivitas Pembelajaran Daring

Pendidikan Islam. Jurnal Al-Mau'izhoh, volume 2(2), November, 2020. Diambil

dari: https://id.wikipedia.org/wiki/Pendidikan_jarak_jauh

Rizqon. Halal Syah Ali. (2020). Dampak Covid-19 pada Pendidikan di Indonesia: Sekolah, Keterampilan, dan Proses Pembelajaran. Jurnal Sosial dan Budaya Syar-I, Volume. 7(5). 2020, hal: 395-402, DOI: 10.15408/sjbsbs.v7i5.15314.

Sugiyono. (2011). Metode Peneltian Kuantitatif, Kualitatif, dan $R \& D$. Bandung: Alfabeta.

Suyahman. (2020). Pelaksanaan Pendidikan Karakter Melalui Gerakan Pramuka di Era Pandemi Covid-19. Jurnal Pendidikan, volume 29(2), Juli 2020, hal: 169-176. http://journal.univetbantara.ac.id/index.php/jp/article/view/803/603

Wahyu. Aji,.\& Fatma. Dewi. (2020). Dampak Covid-19 Terhadap Implementasi

Pembelajaran Daring di Sekolah Dasar. Jurnal Ilmu Pendidikan, Volume 2 (1)

April 2020, hal: 55-61. 